\title{
PLANT WATER RELATIONS AND DROUGHT ADAPTATIONS OF SCHIMA WALLICHII AT PHULCHOWKI HILL, NEPAL
}

\author{
K. Poudyal \\ Amrit Science Campus, Lainchor, Kathmandu, Nepal.
}

\begin{abstract}
In the central Himalaya, plants are subjected to a prolonged dry period, thus developing moisture stress. Variations in water relations and their response to drought in a Himalayan tree species, Schima wallichii at $1400 \mathrm{~m}$ elevation were studied at Phulchowki Hill, Kathmandu, Nepal. To understand the adaptational strategy of this species through which it withstands water stress, different parameters such as soil water potential at $15\left(\Psi_{15}\right)$ and $30\left(\Psi_{30}\right) \mathrm{cm}$ depths, tree water potential at predawn $\left(\Psi_{\mathrm{pd}}\right)$ and midday $\left(\Psi_{\mathrm{md}}\right)$, leaf conductance during morning $\left(\mathrm{g}_{\mathrm{w} \mathrm{AM}}\right)$ and afternoon $\left(\mathrm{g}_{\mathrm{w}} \mathrm{PM}\right)$ and correlation between all these variables were measured from December 1998 to April 2001, except during monsoon months. There was significant variation among months and years in $\Psi_{\mathrm{pd}}, \Psi_{\mathrm{md}} \mathrm{AM}_{\mathrm{AM}}$ and $g \mathrm{w}_{\mathrm{PM}}$. Mean $\Psi_{\mathrm{pd}}$ and $\Psi_{\text {md }}$ were -0.20 and $-0.63 \mathrm{MPa}$, respectively. The minimum $\Psi$ value was observed in March 1999, after 4 months of unusually no rainfall. Some patterns of $\Psi_{\mathrm{pd}}$ were related to phenology and leaf damage as $\Psi_{\mathrm{pd}}$ often increased during leafing. Mean $g_{\mathrm{w} \mathrm{AM}}$ and $g_{\mathrm{w} \mathrm{PM}}$ were 95 and $75 \mathrm{~m} \mathrm{molm}^{-2} \mathrm{~s}^{-1}$, respectively. Schima wallichii maintained high $\Psi$, with low stomatal conductance reflecting its inherent dehydration postponement adaptation.
\end{abstract}

Keywords: Leaf conductance; Phenology; Schima wallichii; Water potential.

\section{INTRODUCTION}

The natural vegetation of the central Himalaya reflects a strong and extensive environmental gradient. The climate is characterized by concentrated warm season rainfall followed by a subsequent 8-9 month of dry season (winter and early summer) and reflects a subterranean effect on plant adaptation and ecosystem processes (Zobel and Singh 1997). The role of environment, particularly drought, in controlling the distribution and performance of Himalayan species, is poorly understood (Zobel and Singh 1995, Poudyal et al. 2003, 2004).

Water moves from the soil through plants to the atmosphere along potential gradient, caused primarily by changes in leaf water potential as a result of transpiration, the lowest plant water potential being at the leaf surface (Lambers et al. 1998). Tree water potential and its components play an important role in the physiology and metabolism of plants (Kramer and Boyer 1995). One of the most important aspects of the water relations in higher plants is the maintenance of a perfect water balance. Predawn water potential $\left(\Psi_{p d}\right)$ varies along environmental gradients (Körner 2003), indicating how plants integrate soil water availability; hence, it is a useful measure of plant water status (Hinckley et al. 1978, Waring et al. 2011) and may correlate with maximum stomatal conductance. To understand the mechanisms that control plant $\Psi_{\mathrm{pd}}$ is vital for the realistic interpretation of plant water use, plant adaptation to stress, and community water balance (Donovan et al. 1999).

The interaction between water availability and sensitivity to water stress affects the phenological behavior of plants (Holbrook et al. 1995). Phenomorphology is associated with soil and tree water status (Borchert $1994 a, b, c)$. There is little information about the role of water in controlling tree phenology of either temperate forests (Hanninen 1995) or those of the Himalaya. Also the satellite data, satellite based products and different methods of modeling (Zhang et al. 2004, Shabanov et al. 2005) is not in practice in this region. As Himalayan trees grow in a climatic region and have a leafing behavior that differs from those of most forests studied (Ralhan and Singh 1987, Singh and Singh 1992, Zobel and Singh 1997), it is unlikely that impinge on their phenology can be determined from other studies. Most dominant Himalayan trees are evergreen with a leaf life span of about 1 year and most of the phenological processes (leaf emergence and expansion, flowering and fruiting) occur primarily at the end of the dry season, when trees still bear old leaves.

To determine the relationships between the Nepal Himalaya dry period, plant and soil water potentials

Author for Correspondence: Kanta Poudyal, Amrit Science Campus, Lainchor, Kathmandu, Nepal. E-mail: kantadidi@gmail.com. 
and leaf conductance, an evergreen angiosperm tree species, Schima wallichii (DC.) Korth. (chilaune) was selected. S. wallichii is a representative of the upper subtropical forest of central Nepal.

\section{MATERIALS AND METHODS}

\section{Study site}

The study was carried out at Phulchowki Hill $\left(27^{0} 33^{\prime} \mathrm{N}\right.$, $\left.85^{\circ} 22^{\prime} \mathrm{E}\right), 10 \mathrm{~km}$ southeast of Kathmandu, Nepal. It is a part of sub-Himalayan Mahabharat region with an altitudinal range of $1400-2715 \mathrm{~m}$ with extensive diverse forests mostly dominated by broad-leaved evergreen trees. It covers an area of approximately $50 \mathrm{sq} \mathrm{km}$ consisting of a vast range of flora. The natural vegetation of Phulchowki Hill is characterized by three distinct evergreen broad-leaved forest types: mixed SchimaCastanopsis forest at the base $(1400 \mathrm{~m}-1800 \mathrm{~m})$, Oak Laurel forest (1800m - 2400m) and evergreen oak forest (2000m above).

The study area has typical warm temperate monsoon climate with three seasons round the year: cold and dry winter (October to February), pre monsoon dry summer (March to May) and monsoon (June to September). There is no perennial source of water above $1600 \mathrm{~m}$ in Phulchowki Hill. Mean long- air temperature ranges between $2.6-18.7{ }^{\circ} \mathrm{C}$ in winter and $15.8-28.2{ }^{\circ} \mathrm{C}$ in summer. Mean long-term annual rainfall is $1882 \mathrm{~mm}$ with about more than $80 \%$ of this occurring between mid-June and mid-September. Relative humidity at 6:30 AM is $>90 \%$ in July, with a minimum of $63 \%$ in April (Poudyal et al. 2003).

\section{MEASUREMENTS}

Water relations such as soil water potential $\left(\Psi_{\mathrm{s}}\right)$ tree water potential $(\Psi)$, leaf conductance $(\mathrm{gw})$, were measured for three representative trees at a monthly interval except for monsoon months. Measurements were taken 28 times from December 1998 to April 2001.One monsoon month's observation was made in September 1999.

Soil water potential was measured with a thermocouple psychrometer (Tru-Psi, Decagon, Pullman WA) by collecting soil within $1 \mathrm{~m}$ of each tree at depths of 15 $\left(\Psi_{15}\right)$ and $30 \mathrm{~cm}\left(\Psi_{30}\right) . \Psi$ was measured on leafy twigs with a pressure chamber (Model 1000, PMS Instrument Corvallis, OR) at predawn ( $\left.\Psi_{\mathrm{pd}}: 0500-0600 \mathrm{~h}\right)$ and midday $\left(\Psi_{\mathrm{md}}: 1300-1400 \mathrm{~h}\right)$.

Five leaves were marked on each sample tree and leaf conductance was measured at 0900-1000h (gwam) and 1300-1400h (gWPM) on each sampling day, along with temperature, relative humidity and light incident on leaf. Leaf conductance was measured with AP4 porometer(Delta-T Devices, Cambridge, U.K.). The porometer was calibrated against a perforated plastic plate of known conductance (Webb 1991). As sampled leaves were shed new leaves were selected.

Phenological observations were done in sampled trees as well as in non-sampled ones for a general acuity. Three twigs were marked on each sampled tree and phenological events such as leaf senescence, leaf emergence, leaf damage, twig emergence, bud formation, flowering and fruiting were tabulated for each month. Senescence was recorded when $>20 \%$ leaves were shed from the trees.

\section{Statistical analysis}

Data were checked for normality. Normally distributed variables or those that could be transformed to normal were analyzed using analysis of variance (ANOVA) and a least significant difference test (LSD) with a 95\% confidence interval. Factors in the ANOVA were sampling month, tree number, year number and their interactions. Spearman rank correlation $(\rho)$ analysis was used to express the relationship between all variables. The statistical package was StatGraphics Plus ver.4.0. (Statistical Graphics Corp., Rockville, MD, USA).

\section{RESULT}

\section{Soil water potential}

Soil water potential at $15 \mathrm{~cm}$ depth $\left(\Psi_{15}\right)$ differed among sampling months $(P<0.001)$. Mean $\Psi_{15}$ was- $0.36 \mathrm{MPa}$ in S. wallichii (Table 1). $\Psi_{15}$ was low during the dry summer months and increased after the monsoon months (Fig.1). In March 1999, after 5 months of almost no rain, $\Psi_{15}$ reached $-1.9 \mathrm{MPa}$. There was significant variation in the years $(P<0.001)$. Mean $\Psi_{15}$ differed significantly within years and $1^{\text {st }}$ year value was lower than $2^{\text {nd }}$ and $3^{\text {rd }}$ years (Table 2). In 2000 and 2001 precipitation was more and $\Psi_{15}$ was higher (Fig.1).

Soil at $30 \mathrm{~cm}$ depth $\left(\Psi_{30}\right)$ was also >-1.0 MPa except in March and April 1999 (Fig. 1). $\Psi_{30}$ showed similar monthly trend as $\Psi_{15}$. Mean $\Psi_{30}$ was $-0.35 \mathrm{MPa}$ (Table 1). Variation was found within years studied $(\mathrm{P}<0.001)$ and mean $\Psi_{30}$ differed within years lowest being the first year of drought (Table 2).

\section{Tree water potential}

There was significant variation in $\Psi_{\mathrm{pd}}$ and $\Psi_{\mathrm{md}}$ in months $(P<0.001)$. Mean $\Psi_{\mathrm{pd}}$ was $-0.2 \mathrm{MPa}$ (Table 1). Predawn water potential showed a profound effect of precipitation and low value was observed during the dry summer month (the minimum values of $\Psi_{\mathrm{pd}}$ was observed in March 1999) and the maximum $\Psi_{\mathrm{pd}}^{\mathrm{pd}}$ occurred during September 1999 and June 2000 the end and commencement of the monsoon period, respectively (Fig.1).

There was significant variation of $\Psi_{\text {pd }}$ with the years sampled $(P<0.001)$ (Table 2$)$. S. wallichii had a consistently high $\Psi_{\mathrm{pd}}$ for $2^{\text {nd }}$ and $3^{\text {rd }}$ years but for the first year of drought $\Psi_{\mathrm{pd}}$ was low and reached to -0.7 MPa (March 1999).

Mean $\Psi_{\text {md }}$ was - $0.63 \mathrm{MPa}$. There was non significant variation among the years studied. $\Psi_{\text {md }}$ was low in February and March 1999 while the highest $\Psi_{\text {md }}$ was observed in September 1999 (Fig.1).

Mean $\Delta \Psi\left(\Psi_{\mathrm{md}}-\Psi_{\mathrm{pd}}\right)$, the diurnal change in tree water status, was $-0.43 \mathrm{MPa}$ (Table 1$)$. 
Table 1: Mean values $( \pm \mathrm{SE})$ of measurements during three sampling years. Mean soil water potential at $15 \mathrm{~cm}\left(\Psi_{15}\right), 30 \mathrm{~cm}$ $\left(\Psi_{30}\right)$, predawn $\left(\Psi_{\mathrm{pd}}\right)$, midday $\left(\Psi_{\mathrm{md}}\right)$ water potential, leaf conductance in morning $\left(\mathrm{g}_{\mathrm{w} \mathrm{AM}}\right)$ and afternoon $\left(\mathrm{g}_{\mathrm{w} \mathrm{PM}}\right)$. Units for $\Psi$

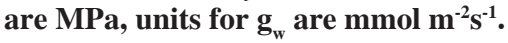

\begin{tabular}{llllllll}
\hline Species & $\Psi_{15}$ & $\Psi_{30}$ & $\Psi_{\mathrm{pd}}$ & $\Psi_{\mathrm{md}}$ & $\Psi_{\mathrm{md}}-\Psi_{\mathrm{pd}}$ & $\mathrm{g}_{\mathrm{w} \mathrm{AM}}$ & $\mathrm{g}_{\mathrm{w} \text { PM }}$ \\
S. wallichii & $-0.36 \pm 0.7$ & $-0.35 \pm 0.6$ & $-0.20 \pm 0.1$ & $-0.63 \pm 0.7$ & $-0.43 \pm 0.6$ & $95 \pm 8.1$ & $75 \pm 11.6$ \\
\hline
\end{tabular}

Table 2 : Mean values of measurements during three sampling years for $\Psi_{15}, \Psi_{30}, \Psi_{\text {pd }}, \Psi_{\text {md, }}, \mathbf{g}_{\mathrm{w} \mathrm{AM}}$ and $\mathbf{g}_{\mathrm{w} \text { PM. }}$ Year $1=$ December 1998 to June 1999, Year 2 = November 1999 to June 2000 and Year $3=$ October 2000 to April 2001. Within columns, different letters indicate significant differences $(P=0.05$, Least Significant Difference).

\begin{tabular}{llllllll}
\hline $\begin{array}{l}\text { Variables } \rightarrow \\
\text { Species }\end{array}$ & Year & $\Psi_{15}$ & $\Psi_{30}$ & $\Psi_{\mathrm{pd}}$ & $\Psi_{\mathrm{md}}$ & $\mathrm{g}_{\mathrm{w}} \mathrm{AM}$ & $\mathrm{g}_{\mathrm{w}} \mathrm{PM}$ \\
S. wallichii & 1 & $-0.9 \mathrm{a}$ & $-0.8 \mathrm{a}$ & $-0.5 \mathrm{a}$ & $-0.7 \mathrm{a}$ & $130 \mathrm{~b}$ & $97 \mathrm{~b}$ \\
& 2 & $-0.3 \mathrm{~b}$ & $-0.25 \mathrm{~b}$ & $-0.12 \mathrm{~b}$ & $-0.6 \mathrm{a}$ & $92 \mathrm{ab}$ & $75 \mathrm{~b}$ \\
& 3 & $-0.25 \mathrm{~b}$ & $-0.22 \mathrm{~b}$ & $-0.13 \mathrm{~b}$ & $-0.7 \mathrm{a}$ & $60 \mathrm{a}$ & $46 \mathrm{a}$ \\
& & & & & & &
\end{tabular}

Table 3: Mean $( \pm \mathrm{SE})$ values of relative humidity $(\mathrm{RH} \%)$, light and temperature $\left({ }^{\circ} \mathrm{C}\right)$ measurements during morning and afternoon stomatal conductance.

\begin{tabular}{lcccccc}
\hline Species & \multicolumn{3}{c}{ Stomatal conductance (AM) } & \multicolumn{3}{c}{ Stomatal conductance (PM) } \\
& RH (\%) & Light & Temperature $\left({ }^{\circ} \mathrm{C}\right)$ & RH $(\%)$ & Light & Temperature $\left({ }^{\circ} \mathrm{C}\right)$ \\
S. wallichii & $71 \pm 3.1$ & $34 \pm 2.9$ & $16 \pm 1.5$ & $44 \pm 3.2$ & $32 \pm 3.6$ & $24 \pm 1$
\end{tabular}

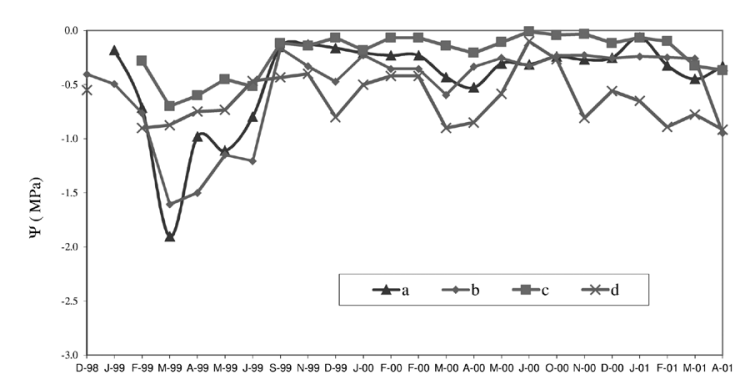

Figure 1 : Mean soil $\Psi_{15}, \Psi_{30}, \Psi_{\mathrm{pd}}$ and $\Psi_{\mathrm{mat}}$ in $S$. wallichii (a= soil $\Psi_{15}, \mathrm{~b}=\operatorname{soil} \Psi_{15}, \mathrm{c}=\Psi_{\mathrm{pd}}$ and d $=\Psi_{\mathrm{mdd}}$ ).

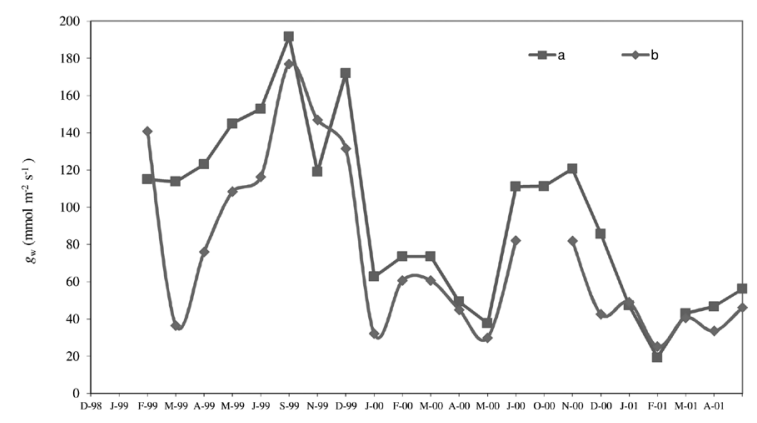

Figure 2: Mean $g_{\mathrm{w}}$ a and $\mathrm{gw}_{\mathrm{PM}}$ in $S$. wallichii . $\left(\mathrm{a}=\mathrm{gw}_{\mathrm{MM}}\right.$ and $\mathrm{b}=\mathrm{gw}_{\mathrm{PM}}$ )

Leaf conductance

Leaf conductance $\left(g_{\mathrm{w}}\right)$ in both morning $\left(\mathrm{g}_{\mathrm{w}}\right.$ AM $)$ and afternoon $\left(g_{\mathrm{w}} \mathrm{PM}\right)$ showed significant variation among months $(P<0.001)$. Mean $\mathrm{g}_{\mathrm{w} \mathrm{AM}}$ was $95 \mathrm{mmol} \mathrm{m}^{-2} \mathrm{~s}^{-1}$. Mean $\mathrm{g}_{\mathrm{w} \mathrm{AM}}$ and $\mathrm{g}_{\mathrm{w} \text { PM }}$ in $S$. wallichii differed during the years observed with high value in $1^{\text {st }}$ year's observation and low in $3^{\text {rd }}$ year (Table 2).
Mean monthly $\mathrm{g}_{\mathrm{w}}$ aM ranged from 19. $3 \mathrm{mmol} \mathrm{m}^{-2} \mathrm{~s}^{-1}$ (January 2001) to $191.6 \mathrm{mmol} \mathrm{m}^{-2} \mathrm{~s}^{-1}$ (September 1999) (Fig. 2).

Mean $\mathrm{g}_{\mathrm{w} \text { PM }}$ was $75 \mathrm{mmol} \mathrm{m}^{-2} \mathrm{~s}^{-1}$ and ranged from 25.1 mmol m $\mathrm{m}^{-2} \quad$ (January 2001) to $176.9 \mathrm{mmol} \mathrm{m} \mathrm{m}^{-2} \mathrm{~s}^{-1}$ (September 2000) (Fig.3). $g_{w}$ AM was higher than $g_{w}$ PM in S. wallichii in dry summer (Fig.2).

Mean RH ( $\left.\mathrm{g}_{\mathrm{wAM}}\right)$ was $71 \%$ and higher than RH ( $\left.\mathrm{g}_{\mathrm{w} \mathrm{PM}}\right)$ (44\%) while there was not much difference between light intensity between morning and afternoon observations. Mean morning temperature was $16^{\circ} \mathrm{C}$ while mean afternoon temperature was $24^{\circ} \mathrm{C}$ (Table 3 ).

\section{DISCUSSION}

Seasonal variation of soil water potential $\left(\Psi_{s}\right)$ in the studied species complemented the pattern of precipitation as the lowest $\Psi_{\mathrm{s}}$ was recorded at both depths during March 1999, the driest period when there had been only $5.4 \mathrm{~mm}$ rainfall at the end of five months. Poudyal et al. (2004) reported very low value of $\Psi_{15}$ i.e. -4.9 Mpa in Castanopsis indica, co-occurring with $S$. wallichi in the same period. Zobel et al. (2001) found low soil $\Psi(-3.51 \mathrm{MPa})$ in oaks in the Central Indian Himalaya during the dry season of 1995 when $60 \mathrm{~cm}$ deep soil averaged $<-1.8 \mathrm{MPa}$. In the present study the seasonal trend of soil water potential indicated that the effect of monsoon precipitation remained up to early winter months and reached to the lowest value before the onset of monsoon. However, occasional 
replenishment of $\Psi_{\mathrm{s}}$ was done by pre-monsoon and winter precipitation in the later years of observation. Thus during 3 years of observations, $\Psi_{\mathrm{s}}$ displayed three patterns, $1^{\text {st }}$ year with lowest $\Psi_{\mathrm{s}}$ due to no precipitation for 5 months, a moderate $2^{\text {nd }}$ year with gradual decline in $\Psi$ from November when dry season progressed and the $3^{\text {rd }}$ year where $\Psi_{\mathrm{s}}$ declined from February onwards. $\Psi_{30}$ was higher than $\Psi_{15}$ and correlated significantly with $\Psi_{15} . \Psi_{\text {s }}$ followed the trend of increasing precipitation effectiveness associated with increasing elevation as $\Psi_{15}, \Psi_{30}$ were higher at lower elevation i.e. S. wallichii site. But a very low $\Psi_{\text {s }}$ was reported by Poudyal et al. (2004) in C. indica. Such differences on the same site might be due to the differences in rooting depth, microhabitat, capacity to extract water, or capacity to replenish transpiration by twig conductance.

$\Psi_{\mathrm{pd}}$ has been considered a good indicator of $\Psi_{\mathrm{s}}$ (Kramer and Boyer 1995) because equilibrium may be established in the soil-plant-atmosphere continuum before dawn. Both $\Psi_{\mathrm{pd}}$ and $\Psi_{\mathrm{md}}$ exhibited seasonal variations as $\Psi_{\mathrm{s}}$. The seasonal patterns of precipitation showed profound effect on average $\Psi_{\text {pd. }} \Psi_{\text {pd }}$ was $>$ $50 \%$ lower in first year than second and third year's observations. However, the relatively lower $\Psi_{\mathrm{s}}$ than $\Psi_{\mathrm{pd}}$ in the sampled species during most of the dry months indicated that root didn't procure water at this depth but depended upon deeper soil water reserves because soil water availability increases with soil depth (Abrams 1990). Furthermore, soil at $25-30 \mathrm{~cm}$ dries faster due to greater root biomass (Ishikawa and Bledsoe 2000) in addition to evaporation of associated ground vegetation that might have resulted lower soil water potential. The reason for lower $\Psi_{\mathrm{pd}}$ than soil $\Psi$ in winter months, when ground herbaceous vegetation almost dried out might be due to low temperature that decreased water movement from the soil into the roots thus reducing plant $\Psi$.

S. wallichii maintained a relatively high $\Psi_{\mathrm{pd}}$ which indicated that it might have shallow roots, which enabled it to draw more water from the soil. In $S$. wallichii $\Psi_{\mathrm{pd}}$ ranged from - 0.1 to - $0.9 \mathrm{MPa}$. Pokharel (2001) and Bhattarai (2001) reported a mean value $0.4 \mathrm{MPa}$ and - 0.7 MPa respectively in S. wallichii from Hetauda at 487 and $689 \mathrm{~m}$, a lower elevation part of the country suggesting a decline in $\Psi_{\mathrm{pd}}$ at higher elevation. Zobel et al. (2001) reported a similar decline in $\Psi_{\mathrm{pd}}$ at higher elevation without a significant relationship between $\Psi_{s}$ and elevation in central Indian Himalaya.

A diurnal change $\left(\Psi_{m d}-\Psi_{p d}\right)$, which is the ability of plants to recover water $\Psi$ diurnally that is lost through leaf conductance, also reflected the seasonal change. $\Psi_{m d}-\Psi_{p d}$ increased in dry months but with further decline in $\Psi_{\mathrm{pd}}$ it decreased sharply. Further low illumination on hazy days also played their role in decreasing diurnal change, mostly in winter months. Poudyal et al. (2004) reported a high $\Psi$ amplitude of - $0.81 \mathrm{MPa}$ in Castanopsis indica growing in S. wallichii site. Stomatal responses to water availability in soil, leaf and atmosphere are highly interactive. As soil potential decreases stomatal conductance also decreases at any particular level of evaporative demand (Bond and Kavanagh 1999). In the studied species, stomatal conductance decreased in dry months when tree water potential was at its lowest (Fig. 3). Choat et al. (2006) found early senescence in the dry season to avoid large decrease in leaf $\Psi$.

The conductivity of water from the leaf to air is probably the most sensitive and earliest indicator of the physiological status of the whole plant (Smith and Hollinger, 1991). S. wallichii differed in its sensitivity of $g_{w}$ to plant $\Psi$. Significant correlation was found between $g_{w}$ and $\Psi_{m d}$ but not with $\Psi_{p d}$. Despite a low soil and tree $\Psi$ prevailing from February $1999\left(1^{\text {st }}\right.$ year), S. wallichi kept its stomata open till February and $g_{w}$ partially decreased in March when $\Psi_{30}$ and $\Psi_{\text {pd }}$ reached -1.1 $\mathrm{MPa}$ and $-0.7 \mathrm{MPa}$, respectively. This indicated stomatal closure due to soil drying. As the soil dried, consequently in summer months, conductance decreased, lowering their loss of water with increasing water deficit.

\section{Relationship with phenology}

The phenological processes (leaf and twig emergence, flowering and fruiting) in the studied species take place at the end of dry season. Phenomorphology of these species showed a close affinity to their internal water status and turgor maintenance. Besides the occasional rise in $\Psi_{p d}$ during the phenologically active periods, plants depended on their stem water storage for the rehydration during phenological activities. Stem water storage played an important role in rehydration of the twigs and also compensated for the transpirational water loss. Individual shift in the timing of phenological events as a consequence of seasonal stress was very common in this species.

There was occasional rise in $\Psi_{p d}$ during the dry season which could be related to the phenological development of the species beside intermittent pre monsoon rain, reduced leaf area or the changes that increase water uptake. Phenomorphological effects are observed by many researchers as a consequence of tree-water status: leaf expansion (Meinzer et al. 1983), bud break, shoot growth and flowering of trees (Reich and Borchert 1984). The phenological processes such as leaf drop, leaf emergence, flowering and fruiting occurred in the dry summer months as in the temperate trees of Indian Central Himalaya (Ralhan et al. 1985) but in contrast to other tropical and temperate species where that is accomplished during early rainy season (Borchert $1994 a, b, c$ ). The studied species showed close phenological affinities with its internal water status as shown by a marginally high $\Psi_{\text {pd }}$ in February 2000 and January 2001 despite low precipitation when leaf emergence started. Besides S. wallichii showed a phenomorphological dependence on $g_{w}$. As leaf 
senescence and emergence takes place from January onwards and plant bears old yellow and newly flushed young leaves inept of an efficient conductance during this period, $g_{w}$ decreased from January onwards (Fig. 3). High morning conductance from March- April to December might be due to fully expanded leaves that are capable of maximum carbohydrate assimilation. However, the lower conductance in March-April (2000) was due to a delayed senescence and late leaf emergence (delayed by two months). Similarly, comparatively lower conductance in $3^{\text {rd }}$ year's observation was due to a prolonged senescence (December to March) and high damages in leaves thus, reducing the conducting area. $S$. wallichii had a higher conductance value which may be attributed to is higher $\mathrm{Y}_{\mathrm{pd}}$ and also to lower SLM value $\left(0.64 \times 10^{-2} \mathrm{gm} \mathrm{cm}^{-2}\right)$ and low hydraulic conductance (Poudyal et al. 2003).

An alternative explanation for the rise in $\mathrm{Y}_{\mathrm{pd}}$ in May and June 2000 is the thin canopy caused by lopping of the trees by villagers who collected fodder for farm animals from the forest. A similar increase of $\mathrm{Y}_{\mathrm{pd}}$ in C. indica was reported by Poudyal et al. (2004) when trees were pruned. Lopped trees can have higher $\mathrm{Y}_{\mathrm{pd}}$ than nearby undisturbed trees (Singh and Thompson 1995).

\section{Adaptation of species along altitudinal gradient}

The present investigation has been an effort to understand the ability of this Himalayan tree species, to endure moisture stress on the basis of its water relations parameters. Water relations properties, especially $g_{w}$, have been used to explain ecological behavior of trees (Lambers et al. 1998, Gao et al. 2003). The studied species showed significant moisture stress only during the pre monsoon season of 1999, when rainfall was negligible and predawn Y dropped to $-0.7 \mathrm{MPa}$. Water stress was not so severe in the following years of observations as occasional replenishment was done by sporadic pre monsoon and winter precipitation. It may be that atmospheric drought at low elevations limited the rate of water loss a tree could maintain.

In a natural ecosystem, decisive factors for the survival or competitiveness of a species are the effectiveness of the adaptive mechanism such as differences in the exploration of soil water by roots and regulation of stomata to prevent tree water potential falling below the threshold value at which xylem cavitation occurs. Seasonal variations of precipitation were reflected by the both species as the depletion in water availability greatly affected their water relations parameters. As the plants grow in typical seasonality of rainfall in Himalayas, they displayed a different adaptational strategy to efface water stress. Schima wallichii which had consistently high $\mathrm{Y}$ and low $g_{\mathrm{w}}$, even during the dry period of 1999, reflected its inherent dehydration postponement adaptation and was better able to avoid water stress (drought avoidence).

\section{ACKNOWLEDGEMENTS}

I would like to express our thanks to Prof. Dr. P. K. Jha, Head, CDB, Tribhuvan University, Prof. Dr. D. B. Zobel, Oregon State University for their guidance. I would also like to acknowledge thanks to Dr. B. B. Shrestha, K. Mainali, N. Adhikari, K. Parajuli, K. Pokharel and R. Tripathee for their help during the field study and National Science Foundation for funding.

\section{REFERENCES}

1. Abrams, M. D. 1990. Adaptations and responses to drought in Quercus species in North America. Tree Physiology. 7: 227-238.

2. Bhattarai, K. 2001. Study of water relations and phenology of Schima wallichii (DC.) Korth and its adaptive strategies to drought in Churia Hill (Makwanpur district). M. Sc. dissertation. Tribhuvan University, Kirtipur, Kathmandu, Nepal. p.79.

3. Borchert, R. 1994a. Water status and development of tropical trees during seasonal drought. Trees. 8: 115-125.

4. Borchert, R. 1994b. Induction of rehydration and bud break by irrigation or rain in deciduous trees in tropical forests. Biotropica. 24: 385-395.

5. Borchert, R. 1994c. Soil and stem water storage determine phenology and distribution of tropical dry forest trees. Ecology. 75: 1437-1449.

6. Bond, B. J. and Kavanagh, K. L. 1999. Stomatal behavior of four woody species in relation to leaf-specific hydraulic conductance and threshold water potential. Tree Physiology. 19: 503-510.

7. Choat, B., Ball, M. C., Luly, J. G., Donnelly, C. F. and Holtum, J. A. M. 2006. Seasonal patterns of leaf gas exchange and water relations in dry rain forest trees of contrasting leaf phenology. Tree Physiology. 26: 657-664.

8. Donovan, L.A., Grise, D. J., West, J. B., Pappert, R. A., Alder, N. N. and Richards, J. H. 1999. Predawn disequilibrium between plant and soil water potentials in two cold desert shrubs. Oecologia. 120: 209-217.

9. Hanninen, H. 1995. Effects of climate change on tree from cool and temperate regions: an ecophysiological approach to modeling of bud burst phenology. Canadian Journal of Botany. 73: $183-199$

10. Hinckley, T. .M., Lassoie, J. P. and Running, S. W. 1978. Temporal and spatial variations in the water status of forest trees. Forest Science Monograph. 20: 1-72.

11. Holbrook, N. M., Whitebeck, J. L. and Mooney, H. A. 1995. Drought response of neotropical dry forest trees. In: Seasonally Dry Tropical Forest. eds. S. H. Bullock, H. A. Mooney and E. Medina. University Press, Cambridge, UK. p. 243-276.

12. Gao, Q., Peng, S., Zhao, P., Zeng, X., Cai, X., Yu, M., Shen, W. and Liu, Y. 2003. Explanation of vegetation succession in subtropical southern China based on ecophysiological characteristics of plant species. Tree Physiology 23: 641-648.

13. Ishikawa, M. C. and Bledsoe, C. S. 2000. Seasonal and diurnal patterns of soil water potential in the rhizosphere of blue oaks: evidence for hydraulic lift. Oecologia. 125: 459-465.

14. Kramer, P. J. and Boyer, J. S. 1995. Water relations of plants and soils. Academic Press. San Diego. p. 495.

15. Körner, C. 2003. Alpine Plant Life: Functional Plant Ecology of High Mountain Ecosystems. Springer. p. 289. 
16. Lambers, H., Chapin III, F. S. and Pons, T. L. 1998. Plant Physiological Ecology. Springer Verlag, New York, USA. p. 533.

17. Meinzer, F., Seymour, V. and Goldstein, G. 1983. Water balance in developing leaves of four savanna woody species. Oecologia. 60: $237-243$.

18. PCARR. 1980. Standard Methods of Analysis for Soil, Plant Tissue, Water and Fertilizer. Philippines Council for Agriculture and Resource Division, Los - Banos, Philippines. p. 194.

19. Pokharel, K.R. 2001. Water relations, phenology and adaptive behaviour of Schima wallichii (DC.) Korth in Hetauda (Makwanpur district). M. Sc. dissertation. Tribhuvan University, Kirtipur, Kathmandu, Nepal. p. 75.

20. Poudyal, K. 2004. Plant Water Relations Of Some Selected Himalayan Tree Species at Phulchowki Hill, Kathmandu. Ph. D. Thesis. Tribhuvan University. p. 167.

21. Poudyal, K., Jha, P. K. and Zobel, D. B. 2003. Seasonal changes in hydraulic conductance of Himalayan trees in respose to drought. Ecoprint 10: 59-73.

22. Poudyal, K., Jha, P. K., Zobel, D. B. and Thapa, C. B. 2004. Patterns of leaf conductance and wter potential of five Himalayan tree species. Tree Physiology. 24: 689-699.

23. Ralhan, P. K. and Singh, S. P. 1987. Dynamics of nutrient and leaf mass in central Himalayan forest trees and shrubs. Ecology. 68: $1974-1983$.

24. Ralhan, P. K., Khanna, R. K., Singh, S. P. and Singh, J. S. 1985. Phenological characteristic of the tree layer of Kumaon Himalayan forests. Vegetatio. 60: 91-101.

25. Reich, P. B. and Borchert, R. 1984. Water stress and tree phenology in a tropical dry forest in the lowland of Costa Rica. Journal of Ecology. 72: 61-74.

26. Shabanov, N. V., Huang, D., Yang, W., Tan, B., Knyazikhin Y. and Myneni, R. B. 2005. Analysis and optimization of the MODIS Leaf Area Index algorithm retrievals over broadleaved forests. IEEE Transactions on Geoscience and Remote Sensing. 43: $1855-1865$.

27. Singh, J. S. and Singh, S. P. 1992. Forest of Himalaya: Structure, Functioning and Impact of Man. Gyanodaya Prakashan, Nainital, India. p. 294.

28. Singh, K.A. and Thompson, F. B. 1995. Effect of lopping on water potential, transpiration, regrowth, ${ }^{14} \mathrm{C}$-photosynthate distribution and biomass production in Alnus glutinosa. Tree Physiology. 15: 197-202.

29. Smith, W. K. and Hollinger, D. Y. 1991. Measuring stomatal behaviour. In: Techniques and Approaches in Forest Tree Ecophysiology. eds. J. P. Lassoie and T. M. Hinckley. CRC Press, Boca Raton, Florida, USA. p. 141-174.

30. Webb, N. 1991. AP4 Porometer User Manual. Delta-T Devices LTD, Cambridge, England. p. 189.

31. Zhang, X., Friedl, M. A., Schaaf, C. B. and Strahler, A. H. 2004. Climate controls on vegetation and phenological patterns in northern mid- and high latitudes inferred from MODIS data. Global Change Biology. 10: 1-13.

32. Zobel, D. B. and Singh, S. P. 1995 Tree water relations along the vegetational gradient in Himalayas. Current Science. 68: 742 745 .

33. Zobel, D. B. and Singh, S. P. 1997. Himalayan forest and ecological generalizations. Bioscience. 47: 735-745.

34. Zobel, D. B., Ram, J. and Bargali, S. S. 1995. Structural and physiological changes in Quercus leucotrichophora and Pinus roxburghii associated with stand disturbance in the Kumaun Himalaya. International Journal of Ecology and Environment Science. 21: 45-66.

35. Zobel, D. B., Garkoti, S. C., Singh, S. P., Tewari, A. and Negi, C. M. S. 2001. Patterns of water potential among forest types of the central Himalaya. Current Science. 80: 774-779. 